\title{
BILINGUAL EDUCATION: THE HISPANIC RESPONSE TO UNEQUAL EDUCATIONAL OPPORTUNITY
}

\author{
Peter D. Roos
}

It is appropriate that a volume which is primarily about desegregation also includes an article on bilingual education. Hispanics, who are the nation's second-largest minority enrolled in public schools, ${ }^{1}$ often perceive bilingual education as paramount in their quest for equal educational opportunity. A common sentiment among Hispanics ${ }^{2}$ in 1978 is that desegregation is a method of achieving equal educational opportunity for blacks, and that for Hispanics to overcome the effects of decades of discrimination, the primary focus should be on bilingual and bicultural education. In many Hispanic communities desegregation is seen as an impediment to equal educational opportunity rather than an aid.

This is not to deny that many Hispanic communities have gone to court to break the patterns of de jure segregation that have afflicted them. ${ }^{3}$ Indeed, seven years before Brown $I,{ }^{4}$ Chicano plaintiffs successfully overturned a pol-

\footnotetext{
* Director, Education Litigation, Mexican American Legal Defense and Educational Fund. The author has represented the plaintiffs in several of the cases discussed in this article.

1. U.S. Dep't of Health, Educ., \& Welfare, Office of Civil Rights, Directory of Public Elementary and Secondary Schools in Selected Districts: Enrollment and Staff by RaCiad/Ethnic Group, at vii (1972).

2. While the concern for bilingual education is shared by many linguistic minorities, see, e.g., Lau v. Nichols, 414 U.S. 563 (1974) [hereinafter cited as Lau] Hispanics comprise the largest such minority. According to a recent survey by the United States Bureau of the Census there are 11.1 million Hispanics in the United States, comprising 5.3\% of the overall population. Also, a greater percentage of Hispanics tend to be of school age: according to this study, $44 \%$ of Hispanics are under eighteen years of age, while $31 \%$ of the overall population are in this age category. Dep't of Commerce, U.S. Bureau of the Census, Population Profile of the United States: 1976, Current Population Reports: Population Statistics, Ser. P-20, No. 307, at 41 (April 1977).

3. The extent to which Mexican American students in the Southwest have been denied equal educational opportunity has been well documented in a series of reports by the U.S. Commission on Civil Rights. See U.S. Comm'n on Civil Rights, Ethnic Isolation of Mexican Americans in The Public Schools of the Southwest (1971) [hereinafter cited as Ethnic Isolation]; The Unfinished Education: Outcomes for Minorities in the Five Southwestern States (1971); The Excluded Student: Educational Practices Affecting Mexican Americans in the Southwest (1972); Mexican american Education in Texas: A function of Wealth (1972); Teachers and Students: Classroom Interaction in the Schools of the Southwest (1973); Toward Equality of Education for Mexican Americans (1974). The term Hispanic includes Mexican Americans, Puerto Ricans, Cubans, and other Latin Americans, but most of the litigation covers the first two groups. Seventy percent of all Hispanic students-almost all of whom are Mexican Americans--attend school in five southwestern states. ETHNic Isolation, supra, at 59.
}

4. Brown v. Board of Educ., 347 U.S. 483 (1954). 
icy of segregation in one California community. ${ }^{5}$ In recent years Chicano communities have sought judicial desegregation throughout the Southwest, ${ }^{6}$ and many communities will continue to demand an end to state-imposed ethnic isolation. Nonetheless, for the moment and for the foreseeable future bilingual-bicultural education will be seen as the sword for severing the bonds that hold back Hispanic children.

This article begins with a brief history of bilingual education in this country. It then discusses the nature of the right to a bilingual education-that is, Who is entitled to a program of bilingual education? Under what circumstances does a school district have an affirmative duty to provide such a program? What is the nature of the program that must be provided? ${ }^{7}$ The article also discusses who is directly responsible for bilingual instruction-that is, whether the teachers must be truly bilingual and whether certification requirements and seniority provisions are relevant to them. The final section of the article focuses on the potential conflict between court-mandated desegregation and the desires of Hispanics to preserve bilingual programs.

5. Mendez v. Westminster School Dist., 64 F. Supp. 544 (S.D. Cal. 1946), aff'd, 161 F.2d 774 (9th Cir. 1947).

6. See, e.g., Cisneros v. Corpus Christi Independent School Dist., 324 F. Supp. 599 (S.D. Tex. 1970), aff'd in part, modified in part. 467 F.2d 142 (5th Cir. 1972), cert. denied, 413 U.S. 920 (1973); Soria v. Oxnard School Dist., 386 F. Supp. 539 (C.D. Cal. 1974).

7. There are a variety of approaches to bilingual education and considerable controversy surrounds their use. See, e.g., N. E.pstein, Language, Ethnicity, and Schools: Policy AlternaTives for Bilingual Education (1977). The simplest approach is to provide English as a Second Language (ESL) instruction. An ESL program is an intensive program to teach children of limited English-speaking ability (LESA) English. It does not provide instruction in the child's native language nor does it usually include teaching the child about his culture. Under the usual ESL program, a child receives his regular subject matter instruction in classes with his Englishspeaking classmates and is removed from the regular classroom for the ESL program.

Distinct from the ESL programs are the several forms of bilingual instruction. The most commonly used approach to bilingual instruction is the transitional bilingual program. In a transitional bilingual program, a child of limited English-speaking ability (LESA) receives his basic instruction in his subject matter courses (e.g., arithmetic and social studies) as well as his language skills in his native language until he is capable of functioning adequately in English. Students in bilingual programs will also receive intensive English language instruction. Many transitional programs attempt gradually to wean LESA students away from their native language by first providing all of the substantive instruction in the LESA students' native language and then increasing the amount of English used in the instruction of the substantive courses.

By contrast, under the bilingual maintenance approach, a LESA student may remain in a native language classroom for as long as he or his parents desire. Although intensive English language instruction is provided, students are not compelled to move into a regular English-speaking classroom after they have mastered the English language. Both bilingual methods usually include instruction in the LESA student's culture.

One commentator has identified more than 400 types of bilingual education programs, depending on their goals (e.g., assimilationism or pluralism), the extent of subject matter taught in each language, the number of language groups being served. and so forth. Mackey, A Typology of Bilingual Education, Foreign Language Annals 596 (1970). 
I

\section{A Brief History of Bilingual Education}

Interest in bilingual education is not new. ${ }^{8}$ During the 1700 s non-Englishspeaking settlers often established schools in which their native language was the primary language of instruction. This continued into the nineteenth century as native-language instruction moved into the Middle West with the non-English-speaking settlers. Native-language instruction was perceived as the most effective way of conveying knowledge to the young and preserving the culture of the countries from which their parents had emigrated. Nativelanguage instruction was generally accepted until the late nineteenth century. One historian of the movement has noted, "[A]s late as 1884, a school law was passed in New Mexico which recognized the public Spanish-language elementary schools: 'Each county shall be and constitute a school district in which shall be taught . . reading, writing . . . in either English or Spanish or both, as the directors may determine." "9

Toward the end of the nineteenth century this tolerance for linguistic diversity came to an end. Three primary causes are often cited for this. First, the immigrants at that time in United States history were different from their predominantly Northern European, Protestant predecessors. The immigrants of the late nineteenth century were predominantly Southern European, Balkan, and Asian, and predominantly Catholic and Jewish. In addition to these ethnic and religious differences, these groups differed from earlier immigrants in that they happened to arrive during a period of economic difficulty. These factors caused significant racial and cultural discrimination; the results of this conflict in religion and cultural values were a desire by the majority to cleanse the immigrants by acculturation and a similar desire by the immigrants to shed their foreign identity to avoid this prejudice. ${ }^{10}$

Another reason for the demise of non-English-language instruction at the turn of the century was the wish to create a "unitary Americanism both political and social." "1 One can surmise that this desire for homogeneity was inspired in part by the recent memory of the Civil War and was heavily influenced by the "threat" of newcomers who had not come from democratic countries and who, unless acculturated, might "foster radical movements in the United States." 12

8. See, e.g., A. Leibowitz, Educational. Policy and Political Acceptance: The Imposition of English as the Language of Instruction in American Schools (1971); Zirkel, The Legal Vicissitudes of Bilingual Education, 58 Phi Delta Kappan 409 (Jan. 1977).

9. A. Leibowitz, supra note 8, at 51-52.

10. Id. See also U.S. Comm'n on Civil Rights, A Better Chance to Learn: BilingualBicultural Education 1-10 (1975).

11. Id. at 6 .

12. U.S. Comm'n on Civil Rights, supra note 10, at 6, citing Kopan, Melting Pot: Myth or Reality?, in Cultural Pluralism 43 (E. Epps ed. 1974). 
The two World Wars have also been cited as a factor in the decline of non-English-language instruction. As one commentator has stated:

The nation's xenophobia was no doubt exacerbated by developments in international affairs. Germany and Japan were clearly threatening to the U.S. Domestically, German-Americans and Japanese-Americans bore the brunt as targets of retaliation. In both of these groups bilingual schooling had been practiced extensively. From the beginning of World War I and through World War II bilingual education was officially restrained almost to the point of extinction. ${ }^{13}$

After the Second World War there was a gradual recognition that children with English-language deficiencies were not doing well in school and thus some special English-language assistance might be necessary. In 1946 the first regional conference on the education of Spanish-speaking people in the Southwest was held in Austin, Texas, where it was noted that Englishlanguage deficiencies were a primary obstacle to educational achievement. ${ }^{\mathrm{I}}$ Indeed, at about the same time courts first recognized that Mexican American children were being subjected to ethnic discrimination in the public schools. ${ }^{15}$ During the 1950 s and early 1960 s various school districts, prompted by the well-publicized success of the Army language schools, provided, on their own initiative, English as a Second Language (ESL) instruction for students with English-language deficiencies. ${ }^{16}$

A major breakthrough in the reemergence of native-language instruction occurred in the early sixties with the arrival of the Cubans in Florida. One commentator has explained the success of the Cubans in obtaining nativelanguage public instruction by noting the following differences between them and other Spanish-speaking groups:

1. They were primarily from the upper and middle classes; they were sophisticated in dealing with the "system" and were not reticent about demanding adequate social services.

2. Because many were professionals, they were able to provide their own trained teachers.

3. They were perceived as transient refugees and thus did not present the threat of unwanted change.

4. The United States government wished to show the world that it would help so-called victims of Communism.

13. Gonzalez, Coming of Age in Bilingual/Bicultural Education: A Historical Perspective, 19 IN EQUALITY IN Educ. 5, 7 (1975).

14. U.S. Comm'N on Civil Rights, supra note 10.

15. See Mendez v. Westminster School Dist., 64 F. Supp. 544 (S.D. Cal. 1946), aff'd, 161 F.2d 774 (9th Cir. 1947); Gonzales v. Sheely, 96 F. Supp. 1004 (D. A riz. 1951).

16. See Gonzalez, supra note 13 , at $7-8$. 
5. Most of the early refugees were of European stock and thus did not suffer the curse of racism. ${ }^{17}$

Thus, "the bilingual schools in Miami Beach became unofficial demonstration centers for the nation." 18 Educators throughout the country recognized the worth of what was occurring in Florida, but the legal system had yet to respond.

In 1968 Title VII of the Elementary and Secondary Education Act of $1965^{19}$ was passed. It provided a small amount of funds for pilot programs in bilingual education for school districts which wished to apply. While it mandated nothing, Title VII was a breakthrough in that for the first time in this century a legislative body had acknowledged that linguistically different children might be better served by a linguistically different education. The cycle was nearing completion.

\section{The Legal Source of the Right to Assistance for Students With Limited English Language Skills}

May 25, 1970, was a landmark in the march toward the recognition that uniformity is not equality for linguistically different children. On that day the Department of Health, Education, and Welfare issued a clarifying guideline to one of its regulations promulgated under Title VI of the 1964 Civil Rights Act. ${ }^{20}$ The regulation barred recipients of federal funds from "restrict[ing] an individual in any way in the enjoyment of any advantage or privilege enjoyed by others receiving any service, financial aid, or other benefit under the program." 21 Another provision of that regulation emphasized that a recipient of federal funds "may not . . . utilize criteria or methods of administration which have the effect of subjecting individuals to discrimination" or have "the effect of defeating or substantially impairing accomplishment of the objectives of the program as respect individuals of a particular race, color, or national origin."22

The May 25 memorandum provided the following clarification: "Where

17. Id. at $8-10$.

18. Id. at 10. See also Stencil, Bilingual Education, 2 Editorial Research ReP. 619, 628 (1977).

19. Bilingual Education Act, Pub. L. No. 90-247, $\S 701-02,81$ Stat. 816 (1968) (current version at 20 U.S.C.A. $\$ \S 3221-3223,3231-3233,3241,3242,3251,3252,3261$ (West. Supp. 1979)) [hereinafter cited as Bilingual Education Act].

20. 45 C.F.R. $\$ 80$ (1978); 42 U.S.C. $\$ 2000$ (d) (1976). Title VI bans discrimination "on the ground of race, color or national origin" in "any program or activity receiving Federal financial assistance." 42 U.S.C. $\$ 2000(\mathrm{~d})$.

21. 45 C.F.R. $\$ 80.3$ (b)(1)(iv) (1978).

22. 45 C.F.R. $\$ 80.3$ (b)(2) (1978). 
inability to speak and understand the English language excludes national origin minority group children from effective participation in the educational program offered by a school district, the district must take affirmative steps to rectify the language deficiency in order to open instructional programs to these students." 23

The May 25 memorandum is significant for three reasons. First, it is a legal mandate to provide special assistance to children with English-language deficiencies; it thus differs from a voluntary plan that an enlightened school district may adopt. Secondly, the mandate affects almost every school district in the country: at the present time, virtually all school districts are recipients of federal funds. ${ }^{24}$ It should be noted that the mandate is dependent not on the receipt of categorical bilingual funds such as those available under Title VII but on the receipt of any federal money.

Finally, and very importantly, regulations issued pursuant to Title VI may provide a private cause of action to students in districts that fail to meet the requirements set forth in the regulations. ${ }^{25}$ Thus, although effective nationwide enforcement is dependent upon HEW's manpower and resources, students in a particular school district may not need to wait for HEW to enforce the law, but may be able to sue or negotiate with the district for an appropriate program for students with English-language deficiencies.

In Lau v. Nichols ${ }^{26}$ a unanimous Supreme Court agreed with HEW that

23. 35 Fed. Reg. 11595 (1970) (emphasis added).

24. Of 16,000 operating school districts, 14,000 received federal education aid in 1977-78 (communication from Ms. Jean Parks, Office of Education).

25. While several lower courts have recognized or assumed that Title VI provides a private right of action, e.g., Bossier Parish School Bd. v. Lemon, 370 F.2d 847 (5th Cir.), cert. denied, 388 U.S. 911 (1967); Natonabah v. Board of Educ., 355 F. Supp. 716, 724 (D. N.M. 1973), the Supreme Court has not yet spoken clearly on this point. In Lau, a Title VI claim was brought by a class of individuals, although the question of a private right of action was not raised by the defendants. See Regents of the University of California v. Bakke, 438 U.S. 265, 380 n.1 (1978) (White, J., separate opinion). In Bakke, only four justices have concluded that Title VI may be enforced in a private action, id. at 418-19 (Burger, C.J., and Stevens, Stewart, and Rehnquist, J.J., concurring in part and dissenting in part), while Justice White has determined that "[a] private cause of action under Title VI would, in terms of both of the Civil Rights Act as a whole and that title, not be 'consistent with the underlying purposes of the legislative scheme' and contrary to the legislative intent." Id. at 380 (quoting Cort v. Ash, 422 U.S. 66, 78 (1975)). The remaining four justices did not reach the question.

26. 414 U.S. 563 (1974). The Lau case was brought by non-English-speaking Chinese students, compelled to attend schools where subjects were taught only in English-a language they could not understand-against the San Francisco School System. The plaintiffs challenged the failure of school authorities to take any significant action to rectify the language deficiencies of at least 1800 such students. The Supreme Court held that by failing to affirmatively overcome the English language deficiencies of national origin-minority group children with limited Englishspeaking ability, school officials had violated Title VI of the Civil Rights Act and HEW guidelines promulgated thereunder. The majority opinion noted that "students who do not understand English are effectively foreclosed from any meaningful education." 414 U.S. at 566. 
Title VI required special assistance for students lacking basic English-language skills, as defined by HEW's May 25 memorandum. The majority opinion noted that California's Education Code requires students to meet certain standards of proficiency in English as well as in other prescribed subjects in order to graduate from high school. Thus, as the majority pointed out:

Basic English skills are at the very core of what these public schools teach. Imposition of a requirement that, before a child can effectively participate in the educational program, he must already have acquired those basic skills is to make a mockery of public education. We know that those who do not understand English are certain to find their classroom experiences wholly incomprehensible and in no way meaningful. ${ }^{27}$

In 1974 Congress incorporated the HEW guidelines and the Lau decision into legislation which makes "the failure by an educational agency to take appropriate action to overcome language barriers that impede equal participation by its students in its instructional programs" an unlawful denial of equal educational opportunity. ${ }^{28}$ Moreover, several courts have indicated that the existence of an unconstitutional dual school system is not a prerequisite for a finding that this provision of the Equal Educational Opportunities Act has been violated. ${ }^{29}$

Thus the right of children of limited English-speaking ability (LESA) to some form of language assistance has been established decisively in the past seven years by federal guidelines, case law, and now federal legislation. ${ }^{30}$ However, the definitions of "limited English-speaking ability" and the "appropriate action" to overcome a language barrier that impedes equal participation $^{31}$ have been the subject of much debate and some litigation. These questions are addressed in the following two sections.

27. Id. at 566 .

28. Equal Educational Opportunities and Transportation of Students Act of 1974, $\$ 204(f), 20$ U.S.C. $\$ 1703(\mathrm{f})(1976) .20$ U.S.C. $\$ 1706$ (1976) provides that a person denied rights under this section has an individual cause of action that may be brought in federal court.

Interestingly, one court has indicated, in denying a motion to dismiss, that the language barrier specified in 20 U.S.C. $\$ 1703$ (f) might not be confined to a foreign language barrier, but might also mean the barrier encountered by students who speak "Black English." Martin Luther King Junior Elementary School Children v. Board of Educ., 451 F. Supp. 1324, 1332 (E.D. Mich. 1978).

29. See, e.g., 451 F. Supp. at 1331; Evans v. Buchanan, 416 F. Supp. 328, 339 (D. Del. 1976), modified, 555 F.2d 373 (3d Cir.), cert. denied, 426 U.S. 935 (1976).

30. This article does not address the right to bilingual instruction under state law. Since Massachusetts passed the first bilingual legislation in 1972, MAss. GEN. LAws ANN. ch. 71A (Michie/Law. Co-op 1978), at least eleven states have passed bilingual bills. While some state legislation may exceed most federal requirements (e.g., Massachusetts), typically state legislation only covers certain grades, e.g., TEx. [EDuc.] CoDE ANN. tit. 21, $\$ 21.453$ (b) (Vernon 1972), or is permissive, e.g., ARIz. Rev. Stat. $\$ 15-1098$ (1975). Thus, federal authority must be relied upon to secure the educational rights of most LESA students.

31. 20 U.S.C. $\$ 1703$ (f) (1976). 
III

\section{Who Is Entitled to Special Language Assistance?}

In order to analyze properly the question of who is entitled to bilingual instruction, one must understand several interrelated factors. First, most children who come from families in which a language other than English is spoken are not entirely without English-language skills: thus, there is a need to measure their English-language proficiency against some standard in order to ascertain their entitlement to a bilingual program. Secondly, bilingual education today is usually based upon legislation that is aimed primarily at overcoming English-language deficiencies rather than providing the most compatible environment for language-minority children. Thirdly, there is currently a significant movement toward extending the entitlement to bilingual instruction to any child who believes he can profit by it-irrespective of his Englishlanguage proficiency. This development can be traced to a number of causes: recognition of the weaknesses in our ability to assess language proficiency, recognition of the fact that differences other than language also hold national-origin-minority children back, ${ }^{32}$ and increased ethnic awareness and pride.

The two statutory requirements for special assistance to LESA students are embodied in the May 25 memorandum and the Equal Educational Opportunities Act. The May 25 memorandum requires school districts to "take affirmative steps to rectify the language deficienc[ies]" of all students whose "inability to speak and understand the English language excludes . . . [them] from effective participation in the educational program offered by a school district ...."33 The Equal Educational Opportunities Act makes it a violation for a school district to fail "to take appropriate action to overcome language barriers that impede equal participation by its students in its instructional programs." 34 Thus neither the HEW memorandum nor the statute enacted by Congress specifies a particular type of instructional program or for whom that program is required.

If a child's principal language is one other than English, there is no question of his entitlement to a special language assistance. However, many His-

32. The failure of schools to educate Hispanic children through traditional methods has been well documented. In 1970, 27\% of Mexican Americans 16 years of age and older had graduated from high school while the comparable rate for the U.S. population as a whole, including blacks and Hispanics, was 55\%. 1 U.S. Dept. OF Health, Education, and Welfare, a Study of Selected Socio-Economic Characteristics of Ethnic Minorities Based on the 1970 Census: Americans of SPanish Origins, NO. (OS) 75-120 (July 1974). Only 2.5\% and $1.4 \%$ of the Mexican American males and females respectively were college graduates compared to $12.6 \%$ of the males and $7.8 \%$ of the females in the total U.S. population. 4 U.S. DePT. OF Health, Education, and Welfare, supra. See also U.S. Comm'n on Civil Rights, Mexican American Education STUDY (1971-74).

33. 35 Fed. Reg. 11595 (1970) (emphasis added).

34. 20 U.S.C. $\& 1703(f)(1976)$. 
panic students were born in the United States, speak Spanish at home, and speak both Spanish and English in the streets and in the schoolyard, yet are doing poorly in school. ${ }^{35}$ Many of these students may actually be more proficient in English than in Spanish. Sometimes this English-language dominance is in speaking and understanding rather than in writing, but many students are English dominant on a written examination and Spanish dominant when examined for the ability to speak and understand. ${ }^{36}$

The legislative standards ${ }^{37}$ suggest that any child, irrespective of the language in which he is most proficient, is entitled to special language assistance if he can show that some language "impediment" stemming from his linguistic background is causing "[in]effective" or "[un]equal" participation in a school district's educational program. "Ineffective or unequal participation" has usually been assumed to mean, for children with language "impediments," that they are not doing as well academically as non-linguistic-minority children. ${ }^{38}$ Whether the norm should be local or national or whether standardized tests should even be the basis for measuring academic achievement are questions that have not adequately been addressed.

The more serious questions, however, are whether the student must show a nexus between language and underachievement and, if so, how he is to demonstrate this. The art of language assessment is not sufficiently sophisticated to identify those children who are bilingual and to trace their underachievement to their linguistic background. ${ }^{39}$ Indeed, given the multiple variables that affect academic success, it seems unlikely that there will ever be a

35. See authorities cited at note 32 supra.

36. For a general discussion of the difficulty of linguistic assessment and the educational, social, and political implications which may flow from different approaches, see De Avila \& Duncan, A Few Thoughts about Language Assessment: The Lau Decision Reconsidered, in ProceEdings of the National Conference on Research and Policy Implications, Lau Task force Report 244 (June 1976). The reason that students are frequently dominant in English on written tests but dominant in their native language on tests designed to measure ability to speak and understand is that all of their formal schooling-reading and writing-has been in English.

As Dr. Ricardo R. Fernandez has correctly pointed out with regard to the issue of what constitutes "limited English-speaking ability," a better term would be "limited English language skills" (LELS rather than LESA), since the term "refers to all the linguistic skills (speaking, listening, reading, and writing) which should be taken into consideration when assessing the language needs of children who could potentially take part in bilingual education programs." Letter from Dr. Fernandez, Director, Lau Center, University of Wisconsin-Milwaukee, to National Review Panel on School Desegregation Research, Feb. 15, 1978.

37. See notes 33 and 34 supra and accompanying text.

38. 414 U.S. at 572. For example, the document prepared for the Office of Civil Rights to guide it in its efforts to enforce compliance with Title VI under Lau provides that some attention, the nature of which is uncertain, must be given to English-dominant students from national origin minority homes who are achieving below grade level. OfFice for Civil Rights, U.S. Dep't of Health, Education, and Welfare, Task force Findings Specifying Remedies for Eliminating Past Educational Practices Ruled Unlawful under lau v. Nichols $12-13$ (1975) [hereinafter referred to as Task Force Findings].

39. See discussion accompanying notes 128-55 infra; supra note 32 . 
single test that relates the degree of underachievement to the student's linguistic background. ${ }^{40}$ The most reasonable solution to this dilemma is to infer that the low academic achievement of these students is attributable in part to their linguistic background and to require, in accordance with the legislative standards, that they be offered the opportunity to participate in an appropriate instructional program. Such an approach would serve various goals. First, it would insure that all students with special linguistic needs would have those needs met. Second, it would provide for parental choice, since these students would not be required to participate if they (or their parents) did not wish to do so. ${ }^{41}$ Finally, this approach would place each student in the program with which he is most comfortable, since it can be assumed that this is what he would choose. A bilingual program is likely to be more sensitive to the needs of Hispanic students than a nonbilingual program. Even if the presumption works in some instances to provide programs for some children technically not in need of special assistance, the abysmal educational failure of Hispanic children provided an insensitive education and the danger of overlooking some students who do need language assistance clearly outweigh the possibility of some overinclusion.

The few cases that have dealt with the question of who is entitled to special language assistance have done so uncomfortably and poorly. The most notable case is Aspira of New York, Inc. v. Board of Education. ${ }^{42}$ In that case the district court adopted what was essentially a language dominance test, measuring dominance by relative proficiency in parallel Spanish and English written examinations. The court, while conceding that its information was imprecise and its ability limited, ordered all Hispanic-surnamed students to be given a standardized achievement test in English. All who scored below the twentieth percentile would then be given the same test in Spanish. If a student scored better on the Spanish test, he was to be placed in a Spanish-language classroom; if the student scored better on the English version, he would be returned to the regular classroom.

There were several reasons for this use of a dominance standard. One was the relative novelty of the problem. A more important reason, however, may have been the definition of the class for whom the suit was brought, that is, all Hispanic children whose "English language deficiency prevents them from effectively participating in the learning process and who can more effectively participate in Spanish."43

40. See, e.g., CAl. [Educ.] CodE § 5767.4(b) (West Supp. 1975) (repealed 1977). See also Cardenas \& Cardenas, Chicano-Bright-Eyed, Bilingual, Brown, and Beautiful, Today's Educ., Feb. 1973, at 49 .

41. The right to special-language assistance must not be viewed as compulsory. Given the inevitable segregative dangers and given differences in educational philosophy, parents and older students should be able to opt for the non-bilingual alternative.

42. 394 F. Supp. 1161 (S.D.N.Y. 1975).

43. $394 \mathrm{~F}$. Supp. at 1162 (emphasis added). 
The second court to face this issue ruled in Otero $v$. Mesa County School District No. $51^{44}$ that the plaintiffs had failed to establish that there was a significant number of students in the school district who had real language deficiencies and who could not learn in English. ${ }^{45}$ The court rejected testimony that the admitted academic failures of Spanish-surnamed students could be attributed to language deficiences. ${ }^{46}$ The court held that too many other factors (for example, socioeconomic background) intervened to permit the causal finding requested by the plaintiffs. ${ }^{47}$ The court further held that the mere showing that Spanish was spoken in the homes of Spanish-surnamed students (which was not necessarily the only language spoken by the students) ${ }^{48}$ was insufficient to require a school district to provide special language assistance. Thus the result in the Otero case can be explained by the failure of the plaintiffs to prove the facts necessary to establish a violation of either the fourteenth amendment or Title VI.

The Otero case, however, highlights a serious practical problem that will face plaintiffs in such litigation if the presumption that the low academic achievement of these students is attributable to their linguistic background is not permitted. The expense of testing enough children to show a pattern of denial of opportunity to LESA students may well be prohibitive for most plaintiffs. Resort to the presumption would allow the plaintiffs to establish a class through rather simple discovery, throwing back on the school district the burden of rebutting the presumption. The district would be in a much better position to conduct such testing. Once plaintiffs have been able to establish that large numbers of Hispanic children are achieving at a level below that of their Anglo counterparts, it appears to be a reasonable allocation of litigative burdens to require the school district to show that the low achievement of such students is not attributable to language problems. ${ }^{49}$

\footnotetext{
44. 408 F. Supp. 162 (D. Colo. 1975), vacated on other grounds, 568 F.2d 1312 (10th Cir. 1977).

45. 408 F. Supp. at 171-72.

46. Id. at $165-66$.

47. Id.

48. Id. at 167 .

49. The Office of Civil Rights has balked at using such a presumption to determine whether a district is out of compliance with Lau. Once a district has been found to be in violation of Title VI by other means, however, OCR will require the district, in the case of those students who are from homes where the language spoken is other than English but who themselves are bilingual, predominantly English-speaking, or monolingual in English, to assess their achievement levels in subject matter areas. OCR currently requires remedial assistance where such students score one or more standard deviations below district norms for Anglo students on the school district's own assessment tools in each subject area. Communication from Roy Rodriguez, Equal Education Opportunity Specialist, Office of Civil Rights, to the National Review Panel on School Desegregation Research (Aug. 29, 1978). TASK ForCE Findings, supra note 38 at 12, 13, 22.

The difficulty with using a standardized achievement test, rather than the district's own assessment tools is that "many Anglo children will be scoring below the cutoff point selected; since presumably they have no linguistic interference problems, they weaken the logical support for a pre.
} 
A final issue that is related to the issue of entitlement to language assistance is whether the duty of a school district to take affirmative steps to correct language deficiencies is triggered by the presence of a single LESA student or very small numbers of such students. ${ }^{50}$ The majority opinion of the Supreme Court in Lau v. Nichols did not discuss whether there was any numerical requirement. However, Justice Blackmun, joined by the Chief Justice, stressed that he concurred in the Lau opinion solely because of the size of the affected group:

I merely wish to make plain that when, in another case, we are concerned with a very few youngsters, or with just a single child who speaks only German or Polish or Spanish or any other language other than English, I would not regard today's decision, or the separate concurrence, as conclusive upon the issue whether the statute and the guidelines require the funded school district to provide special instruction. For me, numbers are at the heart of this case and my concurrence is to be understood accordingly. ${ }^{51}$

The language of Title VI implies that the right to special assistance is that of an individual: "[n]o person ... shall, on the ground of ... national origin ... be subjected to discrimination." ${ }^{2}$ HEW regulations implementing Title VI prohibit the recipients of federal funds from denying "individual rights."53 Finally, the language of the Equal Educational Opportunities Act of $1974 \mathrm{im}$ plies that the entitlement to special language assistance is individual and does not require a showing that large numbers of LESA students are involved: "No State shall deny equal educational opportunity to an individual on account of his or her . . . national origin, by . . . the failure by an educational agency to take appropriate action to overcome language barriers." ${ }^{54}$ Nevertheless state legislation often permits or requires different types of instruction depending upon the numbers of children of a given language background that are found in a school or school district. In those states which mandate special programs

sumption that low-scoring children from non-English-speaking backgrounds are doing poorly because of language difficulties." Letter from Norman J. Chachkin, Senior Staff Attorney, Lawyers' Committee for Civil Rights Under Law (formerly Associate Director for Policy, Planning, \& Research of the Office of Civil Rights, HEW), to the National Review Panel on School Desgregation Research (Dec. 5, 1977).

50. See, e.g., Note, Bilingual Education-A Problem of "Substantial" Numbers? Fordham URB. L.J. $561(1977)$.

51. 414 U.S. at 572 (Blackmun, J., concurring). In Lau the school district had failed to provide over 1,800 Chinese school children who did not speak, understand, read, or write English with any assistance in overcoming their language deficiency.

The Otero court emphasized that both Lau v. Nichols and the post-Lau case of Serna v. Portales Municipal Schools, 499 F.2d 1147 (10th Cir. 1974), involved large numbers of LESA students, Otero v. Mesa County Valley School Dist. No. 51, 408 F. Supp. 162, 170-71 (D. Colo. 1975).

52. 42 U.S.C. $\$ 2000$ (d) (1976) (emphasis added).

53. 45 C.F.R. $\$ 80.3($ b)(1) (1978). See also University of Calif. Regents v. Bakke, 438 U.S. 265 , 298-99 (1978).

54. 20 U.S.C. $\$ 1703$ (f) (1976) (emphasis added). This Act further provides that "an individual" has a cause of action for violation of its terms. 20 U.S.C. $\$ 1706$ (1976). 
of instruction for LESA students, the requirement in almost every case is triggered by a specific number of them-from ten or more in a single school ${ }^{55}$ to fifty or more (or 10 percent of the students) in a single school.56 Most statutes, however, are triggered by the presence of twenty or more LESA students in a school district. ${ }^{57}$

The Office. for Civil Rights guidelines for enforcing compliance with Title VI require districts found in violation of Title VI under the standards articulated in Lau $v$. Nichols to submit a special-assistance plan "when the district has twenty or more students of the same language group identified as having a primary or home language other then [sic] English."58 However, the guidelines point out that "a district does have an obligation to serve any student whose primary or home language is other than English." 59 Similarly, California's statute requires a complete program of bilingual instruction when there are fifteen or more LESA students in a single school who are of the same language group, but if this number is not present, California requires an "individual learning program," which must meet federal requirements. ${ }^{60}$

In sum, while a certain number of children of one age and language group in reasonable geographic proximity may be necessary to make the requirement of full bilingual instruction practical, legal authority, as well as common sense, dictates that the absence of these conditions should not completely free a school district of its obligation to provide special remedial language assistance to individual children.

\section{IV}

\section{What Type of Special Language Instruction Is Required?}

Although Lau $v$. Nichols held that any school district accepting federal aid must take "affirmative steps" ${ }^{1}$ to overcome the English-language deficiencies of students with limited English-speaking ability, no specific remedy was required under Title VI. At the outset of the Court's opinion in Lau, Justice Douglas observed:

No specific remedy is urged upon us. Teaching English to the students of Chinese ancestry who do not speak the language is one choice. Giving instruc-

55. Wis. Stat. AnN. $\$ 115.977$ (West Cum. Supp. 1979) (for grades K-3),

56. Colo. Rev. Stat. $\$ 22-24-108(5)$ (a) (Cum. Supp. 1978) (for grades K-3).

57. See, e.g., Ill. Ann. Stat. ch. $122 \S 14 \mathrm{C}-3$ (Smith-Hurd Cum. Supp. 1979); Mich. Comp. Laws Ann. § 380.1153(1) (West Cum. Supp. 1979); Tex. Code Ann. tit. 2, § 21.453(b) (Vernon Cum. Supp. 1978).

58. TASk Force Findings, supra note 38 , at 4.

59. Id. (Emphasis added).

60. Cal. [Educ.] Code $\$ 5767.4$ (b) (West Supp. 1975) (repealed 1977).

61. May 25 Memorandum, 35 Fed Reg. 11595 (1970), implementing 42 U.S.C. \$ 2000(d). In 1974, Congress adopted statutory language resembling the HEW regulations, requiring school districts to take "appropriate action to overcome language barriers." 20 U.S.C. $\$ 1703$ (f) (1976) (emphasis added). Neither "affirmative steps" nor "appropriate action" was defined. 
tions to this group in Chinese is another. There may be others. Petitioners ask only that the Board of Education be directed to apply its expertise to the problem and rectify the situation. ${ }^{62}$

Obviously, then, since the Supreme Court was not asked to rule on the validity of a particular approach, it was unlikely that it would have ventured into such murky waters. The Court referred, however, to the two major alternatives (which have multiple variations): native language instruction (bilingual programs) or intensive remedial English instruction (ESL programs) ${ }^{63} \mathrm{Al}$ though the social science debate still rages over the relative effectiveness of bilingual programs and English-as-a-Second-Language (ESL) programs, ${ }^{64}$ legis-

62. 414 U.S. at 564-65.

63. The arguments for or against the various approaches have been vehement. See, e.g., $A$ Storm Brews Over Bilingual Teaching, U.S. News \& WorLD REP., March 6, 1978, at 58, quoting Professor Josue M. Gonzales' criticism of ESL for "help[ing to] maintain the outdated melting-pot syndrome which discourages cultural pluralism in American society." Id., at 59. The same article quotes Professor Gary Orfield's criticism of current bilingual programs: that they are often "expensive, highly segregated programs of no proven educational value to children." Id. The arguments pro and con are well documented in N. EPSTEIN, supra note 7. See also Stencil, supra note 18 , at $624-26$.

64. The research on bilingual education has been extremely limited. See, e.g., Deane \& Zirkel, The Bilingual Education Mandate, Ам. Sсн. B.J. 29, 30 (July, 1976). Moreover, the research that is available suffers from too many serious methodological defects to allow any conclusions to be drawn. See, e.g., Zirkel, supra note 8 . Thus no definitive conclusions can be drawn from the research about the relative merits of the different approaches for meeting the needs of LESA students. See, e.g., N. EPSTEIN, supra note 7.

The most recent study of the impact of bilingual education on students in both the cognitive and affective domains was undertaken by the American Institutes for Research (AIR) for the United States Office of Education in 1978. The study indicated no gain in student achievernent in either English language skills or in mathematics above what would have been expected had the students been assigned to a traditional classroom and in some cases, comparable students in traditional classrooms made slightly greater gains in English language skills. (This, as the AIR study points out, could be explained by the fact that more time was spent on Spanish language skills instruction in the bilingual classes.) USOE, Evaluation of the Impact of ESEA Title VII Spanish/ English Bilingual Education Program, Final Report Summary, March 1978. This report has been severely criticized by the Center for Applied Linguistics for such methodological defects as the unrealistically short period (five months or less) between the pre-test and post-test administered to the students, for the inappropriateness of the tests used, for the merging of results from good and weak programs and the failure to distinguish among the variety of educational treatments that students received, and the wide differences in language abilities among students studied. Center for Applied Linguistics, Response to AIR Study Evaluation of the Impact of ESEA Title VII Spanish/English Bilingual Education Program, Apr. 18, 1977. See also the extremely critical comments of the AIR study by Dr. José Cardenas, Director of the Intercultural Development Research Association, based on an analysis of the study by that organization. Cardenas, Response I, in N. Epstein, Language, Ethnicity, and the Schools 74-75 (1977).

Other research indicates that bilingual programs facilitate learning, especially in mathematics. See, e.g., Balinsky \& Peng, An Evaluation of Bilingual Education for Spanish Speaking Children, 9 URB. Educ. 271 (1974).

Part of the reason why there is so little research, and why the existing research is inconclusive is that the Bilingual Education Act, 20 U.S.C. $\$ 880 \mathrm{~b}$ (1970 \& Supp. V 1975), under which most programs have been funded, is relatively recent. Secondly, both the Office of Bilingual Education and the National Institute of Education have failed to mount large scale research programs as initially envisioned by Congress in its passage of the 1974 legislation. See especially 20 U.S.C. $\S$ 880 b(13) (1976); 20 U.S.C.A. § 3252 (West Supp. 1979). 
lators, government agencies, and, at times, even the courts seem to have opted for some form of bilingual instruction as the more effective way of insuring equality of educational opportunity.

\section{A. Legislative Support for Bilingual Instruction}

A review of state and federal legislation mandating special language assistance for linguistic minorities indicates a legislative belief that bilingual instruction must currently be assumed to be a more effective approach to the English-language handicaps of linguistic minorities than ESL instruction.

This legislative recognition of the effectiveness of bilingual instruction is clearly featured in the Federal Bilingual Education Act. ${ }^{65}$ The preamble to that Act states that "Congress declares it to be the policy of the United States .... (A) to encourage the establishment and operation, where appropriate, of educational programs using bilingual educational practices, techniques, and methods." 66 A program of bilingual education is defined by the Act as one in which "there is instruction given in, and study of, English and, to the extent necessary to allow a child to achieve competence in the English language, the native language of the children of limited English proficiency."67 Although the language admits of the possibility that ESL programs will be funded, it is the policy of the Office of Bilingual Education to fund only bilingual programs under this legislation. ${ }^{68}$ The House, in reporting out the 1974 bill, $^{69}$ articulated its understanding of what bilingual education involves:

. . . the use of two languages, one of which is English, as the media of instruction in a comprehensive school program. There is evidence that use of the child's mother tongue as a medium of instruction concurrent with an effort to strengthen his command of English acts to prevent retardation in academic skill and performance. The program is also intended to develop the child's self esteem and a legitimate pride in both cultures. Accordingly,

The author, however, is of the deeply pessimistic view that educational research is not likely to shed much light on the subject. The author agrees with the opinion expressed at a meeting on October 5, 1977, which the author attended, by Vice-President Mondale, who as Senator had been a prominent advocate for progressive education policies. He stated that when all the research results were in, one had to trust one's instincts. And it was instinctive knowledge that children learn best in a language they understand. The Vice-President reached this conclusion having summarized his experience that educational research invariably could be found which defined centuries of human observation. He cited especially to research that showed that class size had little relevance to educational achievement. Thus, while the author believes it certainly makes sense to increase interest in bilingual research, it also seems extremely unlikely that additional research will shed much light on the issues of central concern.

65. Supra note 19.

66. Bilingual Education Act, $\$ 702,20$ U.S.C.A. $\$ 3222$ (West Supp. 1979).

67. 20 U.S.C. $\S 880 \mathrm{~b}-\mathrm{l}(\mathrm{a})(4)(\mathrm{A})(\mathrm{i})$ (1976). The 1978 amendment passed by congress and awaiting Presidential signature contains similar language. \$ 703(A)(4) ESEA Amendments (1978).

68. Many school districts, however, used federal funds under this act to provide English as a Second Language (ESL) programs rather than truly bilingual instruction.

69. H.R. ReP. No. 805, 93d Cong. 2d Sess., reprinted in 3 U.S. Code Cong. \& Ad. News 4093 (1974). 
bilingual education normally includes a study of the history and cultures associated with the mother tongue. ${ }^{70}$

In a recent decision by a federal district court in New York this declaration of policy by Congress, together with the Equal Educational Opportunities Act of 1974, Title VI of the Civil Rights Act of 1964, the Supreme Court's interpretation of Title VI, its regulations in Lau v. Nichols, and the "suggestions" of the Lau Remedies guidelines, was construed to require a program of bilingual-bicultural instruction for LESA students. ${ }^{71}$ The court cited with favor the Tenth Circuit's opinion in Serna v. Portales Municipal Schools, which discussed the psychological trauma borne by non-English-speaking students who are taught in English. ${ }^{72}$

State legislation has frequently opted for bilingual instruction. ${ }^{73}$ In the preamble to California's legislation, for example, the following "finding" is stated:

[T] other than English and who do not have the English language skills necessary to benefit from instruction only in English at a level substantially equivalent to pupils whose primary language is English. Their lack of English language communication skills presents an obstacle to such pupils' right to an equal educational opportunity which can be removed by instruction and training in the pupils' primary languages while such pupils are learning English. ${ }^{74}$

In the Illinois legislation the parallel provision to the finding by the California legislature states:

Experience has shown that public school classes in which instruction is given only in English are often inadequate for the education of children whose native tongue is another language. The General Assembly believes that a program of (transitional) bilingual education can meet the needs of these children and facilitate their integration into the regular public school curriculum. ${ }^{75}$

Similarly, the legislation enacted by many other states appears to be based on the general conclusion that bilingual instruction (as opposed to a program

70. Id. at 4148 .

71. Cintron v. Brentwood Union Free School Dist. Bd. of Educ., 455 F. Supp. 57, 62-64 (E.D.N.Y. 1978).

72. Id., at 62, quoting Serna v. Portales Municipal Schools, 499 F.2d 1147, 1150 (10th Cir. 1974)

73. This is a very recent phenomenon. Not too many years ago, states treated the Englishlanguage deficiencies of students as the child's burden to overcome, and not one for which the schools were responsible. Most states prohibited the use of a foreign language as a medium of instruction. Some states imposed criminal penalties on teachers who violated this requirement and punished children who used their native language in the classroom or even on school grounds. See Levin \& Moise, School Desegregation Litigation in the Seventies and the Use of Social Science Evidence: An Annotated Guide, 39 LAW \& ConTemp. Prob., Winter 1975, at 50, 118, and materials cited therein.

74. Cal. [Educ.] Code. $\$ 5767.05$ (West Supp. 1975) (repealed 1977) (emphasis added).

75. Transitional Bilingual Educ., Ill. Ann. Stat. ch. 122, § 14C-2 (Smith-Hurd) (Supp. 1978). 
composed solely of ESL instruction) is the most appropriate response to the English-language deficiencies of LESA students. ${ }^{76}$

\section{B. Administrative and Regulatory Support for Bilingual Instruction}

In the summer of 1975 the Department of Health, Education, and Welfare convened a group of experts to provide it with guidance in the implementation of Lau. The end product of the deliberations of this task force was a document known informally as the Lau Remedies. ${ }^{77}$ That document establishes standards for identifying LESA students, for assessing the degree of their language abilities in their native language and English, for diagnosing each LESA student's educational needs, and for prescribing and implementing the educational program that will satisfy the diagnosed educational needs of the language-minority student. For an elementary student who is identified as a monolingual speaker of a language other than English or whose predominant language is other than English, native language instruction clearly must be provided. ${ }^{78}$ Although the Lau document appears to permit some form of ESL instruction at the secondary level, ${ }^{79}$ it has been argued that this should be read to permit such instruction only in limited circumstances-the most frequently cited example being that of a student who arrives in the United States in the final semester of his senior year. ${ }^{80}$ For the student who is genuinely bilingual, that is, who speaks both English and his native language with equal facility, a further evaluation is needed. If the bilingual student is underachieving, ${ }^{81}$ he must be offered the same program offered all underachievers, regardless of their language background. ${ }^{82}$ There has been considerable criticism of this relatively simplistic approach to the bilingual underachiever. A major problem, as noted earlier, is the difficulty of ascertaining through standardized tests or other instruments whether there is a nexus between low academic achievement and English-language disability or wheth-

76. See the survey of bilingual legislation contained in Center for Applied Statistrcs, The Current Status of U.S. Bilingual Education Legislation legislation (May 1975).

77. Lau Remedies, supra note 38 . While this document is designed to be used only to assess the adequacy of a plan once a finding of a Title VI violation has been made, as a practical matter HEW personnel, due in part to the lack of alternative guidelines, have used it as a sort of benchmark to ascertain initially whether a school district is in compliance in the first instance. See, e.g., letter of Findings re: Corpus Christi I.S.D., September 7, 1977.

78. Lau Remedies, supra note 38 , at 6-7, 9-10.

79. Id. at 7-9, 10-12.

80. Communications between the author and such Task Force members as Dr. José A. Cardenas, Executive Director, Intercultural Development Research Association, and others involved at the federal level such as Lloyd Henderson, Division Director of Technical Review and Assistance, Office of Civil Rights, HEW.

81. The Lau Remedies memorandum defines underachievement as "performance in each subject area (e.g., reading, problem solving) at one or more standard deviations below district norms as determined by some objective measures for non-ethnic/racial miniority students." Id. at 22.

82. Id. at 12 
er poor academic performance is attributable to other factors such as socioeconomic status. ${ }^{83}$ It has been observed that many children who grow up in barrios and are classified as bilingual frequently are weak in both English and their native language. ${ }^{84} \mathrm{~A}$ determination that such students are bilingual because of their inability to speak either language well, which frees school districts from their obligation to provide special language instruction, seems to fly in the face of common sense. HEW appears to have recognized this, and in recent negotiations with the Chicago school board has requested that the linguistic needs of bilingual children be addressed. ${ }^{85}$ Notwithstanding this, the difficult issue of what particular language programs are necessary for the genuinely bilingual underachiever still eludes HEW. Nevertheless, it is fair to say that HEW, through the Lau Remedies, has generally acknowledged the necessity of bilingual instruction as a remedy for the English-language deficiencies of language-minority students.

In addition to the explicit statements in the Lau Remedies, earlier regulations implementing Title VI of the Civil Rights Act may also provide a basis for requiring bilingual instruction. For example, school districts are prohibited from employing "methods .. . which have the effect of . . . substantially impairing accomplishment of the objectives of the program." ${ }^{86}$ If teaching science is the objective of a science class, it seems irrefutable that teaching it in English to non-English-speaking children would substantially impair accomplishment of that objective.

\section{Judicial Support for Bilingual Instruction}

To date three courts have confronted the question whether ESL instruction is an adequate response to a Title VI violation or whether bilingual in-

83. See discussion at notes 32-36 supra and accompanying text. Cf. Serna v. Portales Municipal Schools, 351 F. Supp. 1279 (D.N.M. 1972), aff'd on other grounds, 499 F.2d 1147 (10th Cir. 1974), in which, based on the testimony of an educational psychologist and the results of I.Q. and language expression tests administered to first and fifth grade students, the court found that language difficulties accounted for $\mathbf{8 0 - 8 5}$ percent of the achievement differences between Anglo and Chicano students. 351 F. Supp. at 1281-82.

84. One disturbing example of the problem is that Anglo teachers in California have a higher pass rate on the Bilingual Competency Exam than do Chicanos. Discussion with Roberto Cruz, Director, Bay Area Bilingual Education Laboratory (BABEL).

85. Chicago Public Schools Plan for the Implementation of the Provision of Title VI of the Civil Rights Act of 1964 Related To... Bilingual Education Programs (Oct. 12, 1977), see letter from Conrad Harper, Special Consultant to HEW, to Carey Preston, Vice-President, Chicago Board of Education (June 28, 1971) on file with Mexican American Legal Defense and Education Fund. In that letter he observes: "preliminarily, let me say that based upon the School District's representations, it would seem that additional assessment of students in Level IV [bilingual] would be advisable notwithstanding the fact that all Level IV students are presumptively entitled to bilingual education. Anticipated difficulties in designing appropriate methods and instruction for such assessment-whether because of the number of languages spoken by the students or the elusiveness of the qualities to be measured-should not be allowed to delay the provision of services to which students are entitled."

86. 45 C.F.R. $\S 80.3(b)(2)(1978)$. 
struction should be mandated as a remedy. ${ }^{87}$ In Serna $v$. Portales Municipal Schools ${ }^{88}$ the school district's proposed ESL remedy was deemed an inadequate response to the educational needs of its students. The district court had held that the school authorities' failure to establish a meaningful bilingual educational program for its Chicano students was a violation of the equal protection clause of the fourteenth amendment. ${ }^{89}$ On appeal the Tenth Circuit affirmed the district court's holding, but on the ground that the Portales school system violated Title VI of the Civil Rights Act. In upholding the district court's order to institute a bilingual-bicultural instructional program, the court of appeals noted that under the circumstances of that case $e^{90}$ "the trial court, under its inherent equitable power, can properly fashion a bilingualbicultural program which will assure that Spanish-surnamed children receive a meaningful education." 11 The court summarized some of the social science evidence that supported the district court's order:

Expert witnesses explained what effect the Portales School System had on Spanish surnamed students. Dr. Zintz testified that when Spanish surnamed children come to school and find that their language and culture are totally rejected and that only English is acceptable, feelings of inadequacy and lowered self-esteem develop. Henry Pascual, Director of the Communicative Arts Division of the New Mexico Department of Education, stated that a child who goes to a school where he finds no evidence of his language and culture and ethnic group represented becomes withdrawn and nonparticipating. The child often lacks a positive mental attitude. Maria Gutierrez Spencer, a long time teacher in New Mexico, testified that until a child developed a good self image not even teaching English as a second language would be successful. ${ }^{92}$

87. In Rios v. Read, 73 F.R.D. 589 (E.D.N.Y. 1977), a ruling on a motion by Hispanic plaintiffs to compel a school district sued under Lau to produce certain records, the defendants argued that $L a u$ required a school district to take some affirmative step toward meeting the needs of non-English speaking students and that it need not show whether those steps were effective. The programs provided by the school district involved removal of the LESA students from their regular classrooms for ESL instruction.

The court rejected the argument that any affirmative steps would meet the Supreme Court's mandate in Lau:

It is not enough simply to provide a program for language disadvantaged children or even to staff the program with bilingual teachers; rather, the critical question is whether the program is designed to assure as much as is reasonably possible the language deficient child's growth in the English language. An inadequate program is as harmful to a child who does not speak English as no program at all.

Id. at 595. This case is quoted and discussed in Teitelbaum \& Hiller, Bilingual Education: The Legal Mandate, 47 Harv. Educ. Rev. 138, 149-50 (1977). As the authors point out, Rios v. Read was the first case in which a court had buttressed the holding of Lau by referring to the legislative history of the 1972 amendments to the Bilingual Education Act, see H. R. REP. No. 805, 93d Cong., 2d Sess. (1974), in which Congress emphasized the importance of bilingual education. Teitelbaum \& Hiller, id. at 150. See also Cintron v. Brentwood Union Free School Dist. Bd. of Educ., 455 F. Supp. 57 (E.D.N.Y. 1978).

88. 351 F. Supp. 1279 (D.N.M. 1972), aff'd on other grounds, 499 F.2d 1147 (10th Cir. 1974).

89. Contra, Lau v. Nichols, 483 F. 2d 791 (9th Cir. 1973), rev'd on other grounds, 414 U.S. 563 (1974).

90. 499 F.2d at 1154 .

91. Id.

92. Id. at 1150 . 
The second decision, Cintron $v$. Brentwood Union Free School District,${ }^{93}$ relied upon Serna, Lau v. Nichols, various federal statutes, ${ }^{94}$ and the Lau Remedies guidelines in its ruling that LESA students had a federal right to a bilingualbicultural instructional program with bilingual teachers. ${ }^{95}$ The district's proposed immersion, or ESL, program was held inadequate and in violation of federal law. A third decision, Rios $v$. Read, reached a similar conclusion. ${ }^{96}$

Although Serna, Cintron, and Rios are the only cases in which the relative adequacy of ESL instruction and bilingual instruction has been addressed, several other courts have had occasion to order school districts to provide bilingual educational programs. In a case involving the San Felipe Del Rio school district in Texas ${ }^{97}$ the district court determined that school authorities had established a dual school system, isolating Mexican American students in unconstitutionally segregated schools. As in previous school desegregation suits, the court declared that the relief required was to order the school district to “' 'eliminate discrimination root and branch,' . . . and to create a unitary school system 'with no black [Mexican] schools and no white schools but just schools." "98 But unlike courts in black-white desegregation cases, the court also determined that to create a unitary system and overcome the effects of past segregation a comprehensive plan for bilingual-bicultural instruction was required..$^{99}$

A second case, involving the school system of the City of New York, was settled by consent agreement. ${ }^{100}$ The court in that case approved a consent decree, in accordance with rights articulated in Title VI and the Supreme Court's decision in Lau $v$. Nichols, under which the defendant school district agreed to provide a program of instruction for LESA students involving "intensive training in English language skills, instruction in substantive courses in Spanish, and reinforcement of Spanish language skills." 101

93. 455 F. Supp. 57 (E.D.N.Y. 1978).

94. E.g., Equal Educational Opportunities Act of 1974, $\$ 204,20$ U.S.C. $\S 1703$ (1976). Bilingual Education Act, 20 U.S.C. $\$ 880$ b (1976); Civil Rights Act of 1964, $\$ 601,42$ U.S.C. $\$ 2000 d$ (1976).

95. 455 F. Supp at 64 .

96. 73 F.R.D. 589 (E.D.N.Y. 1977).

97. United States v. Texas, 342 F. Supp. 24 (E.D. Tex. 1971), aff'd per curiam, 466 F.2d 518 (5th Cir. 1972).

98. 342 F. Supp. at 27, quoting Green v. New Kent County Bd. of Educ., 391 U.S. 430 (1968).

99. 342 F. Supp. at 28, 30-33. Contra, Morales v. Shannon, 516 F.2d 411 (5th Cir. 1975), cert. denied, 423 U.S. 1034 (1975), where the court was reluctant to order a specific bilingual educational remedy. "[I]t strikes us that this entire question goes to a matter reserved to educators." Id. at 415. The court did add the observation, however, that it was "an unlawful educational practice to fail to take appropriate action to overcome language barriers," citing the Equal Educational Opportunities Act of 1974 and Lau v. Nichols. Id.

100. Aspira of N.Y., Inc. v. Board of Educ., 394 F. Supp. 1161 (S.D.N.Y. 1975).

101. Id. at 1162 . 
By contrast, the Tenth Circuit, in Keyes $v$. School District No. $1,{ }^{102}$ reversed a district-court order requiring the Denver school district to develop a comprehensive bilingual-bicultural program based on the so-called Cardenas Plan presented by the Congress of Hispanic Educators, who had intervened in what had originally been brought as a black-white desegregation suit. ${ }^{103}$ The Tenth Circuit pointed out that the district court, in adapting the Cardenas plan, was not "merely removing obstacles to effective desegregation [but] . . . impos[ing] upon school authorities a pervasive and detailed system for the education of minority children. We believe this goes too far."104 The circuit court did imply, however, that if there had been proof that the Denver school district's existing "curricular offerings or its methods of educating minority students constituted illegal segregative conduct or resulted from such conduct," ${ }^{105}$ the district court's order would not have "overstep[ped] the limits of its remedial powers." 106 Indeed, the Tenth Circuit appeared to endorse the fact that "a meaningful desegregation plan" must help "Hispano school children to reach the proficiency in English necessary to learn other basic subjects." ${ }^{107}$ Thus the Keyes decision, by the same circuit which had affirmed the extensive bilingual-bicultural education program in Serna,${ }^{108}$ can be explained by the failure to find either that the rights of Hispanic students under Title VI (as interpreted by Lau v. Nichols) or the Equal Educational Opportunities Act had been independently violated or that the remedy was necessary to undo the effects of past segregation. ${ }^{109}$

102. Keyes v. School Dist. No. 1, 521 F.2d 465 (10th Cir, 1975), cert. denied, 423 U.S. 1066 (1976).

103. 380 F. Supp. 673, 694 (D. Colo. 1974).

104. 521 F.2d at 482 .

105. Id.

106. Id, at 481 .

107. Id. at 482 .

108. 499 F.2d 1147 (10th Cir. 1974).

109. This point is particularly important in light of the Supreme Court's recent decision in Milliken v. Bradley, 433 U.S. 267 (1977) (Milliken II). In that case, the State of Michigan had argued that where there has been a finding of unconstitutional segregation of pupils, the court's remedial decree must be limited to pupil assignments. The Supreme Court held, however, that a desegregation plan may include other factors such as educational programming and the retraining of teachers because "discriminatory student assignment policies can themselves manifest and breed other inequalities built into a dual system founded on racial discrimination." Id. at 283. Thus in addition to the statutory Title VI rights under Lau, the Supreme Court has now implied that language minority children are entitled to special language instruction where there has been a finding of unconstitutional segregatory conduct by school officials. And if the evidence shows that bilingual-bicultural programs of instruction are necessary to restore the victims of discrimination to the position they would have occupied in the absence of discrimination, id. at 282 , plans relying on ESL programs would be unlikely to be upheld. 


\section{$\mathrm{V}$ \\ Who Provides Bilingual Instruction?}

Some of the most difficult and potentially explosive issues surrounding bilingual education concern the employment of teachers. The basic problem is that the number of students in need of and entitled to bilingual instruction is not matched by adequate numbers of currently employed teachers with bilingual skills. ${ }^{110}$ This problem must be viewed in the context of two additional forces. First, most school districts are facing the problem of declining total enrollment, though Hispanic enrollment is not declining. ${ }^{11}$ Thus school districts subject to budgetary pressures want to cut back on staff. Secondly, there are increasing numbers of Hispanics graduating from colleges of education who are prepared to meet the special language needs of Hispanic students. The combined effect of these two factors is often tension between the teachers with seniority, who-though not able to provide bilingual instruction-understandably wish to retain their positions, and the growing pool of young teachers who have the skills to provide bilingual instruction. This tension is likely to erupt in acrimonious litigation.

To date only one court has ventured into this thicket. In Cintron $v$. Brentwood Union Free School District ${ }^{112}$ the school district, faced with declining enrollment, was forced to lay off some of its staff. Previously the school district had had a well-regarded, comprehensive program of bilingual instruction for its Puerto Rican students. ${ }^{113}$ When school officials determined that teacher layoffs were necessary, they created a separate tenure system for bilingual and ESL teachers in order to preserve the bilingual program.

Nonbilingual, senior teachers facing dismissal challenged this action of the

110. In 1971 the U.S. Commission on Civil Rights reported the following disparities between Chicano students and Chicano teachers in the states of the Southwest: Texas: $20.1 \%$ of the students are Mexican American compared to $4.9 \%$ of the teachers; California: $14.4 \%$ Mexican American students, 2.2\% Mexican American teachers; New Mexico: 38\% Mexican American students, $16.2 \%$ Mexican American teachers; Arizona: $19.6 \%$ Mexican American students, 3.5\% Mexican American teachers; Colorado: $13.7 \%$ Mexican American students, $2.3 \%$ Mexican American teachers. U.S. Comm'N on Civil Rights, Ethnic Isolation of Mexican Americans in the Public Schools of the Southwest, in Mexican American Education Study, Rep. 1, at 43 (1971).

111. The Houston Independent School District is typical. The overall enrollment has dropped from a high of 241,138 in $1970-71$ to a present enrollment of 106,998 . The Hispanic enrollment during that period increased from 34,759 to 47,128. Houston Independent School District, Membership HISD by Ethnic Group, Exhibit for Doe v. Plyler, No. 77-261 (E.D. Tex. 1977).

The Cintron case, presented the following situation: the school district's enrollment had been declining for the past five or six years at the rate of 500 students a year, although the percent of Hispanic students remained relatively constant during the same period. Cintron v. Brentwood Union Free School Dist. Bd. of Educ., No. 77-C-1310, slip op. at 2 (E.D.N.Y. Aug. 22, 1977). See also Stencil, Bilingual Education, 2 EdTrorial Research Reports 619, 632-33 (1977) (citing Office of Education and GAO estimates).

112. No. 77-C-1310 (E.D.N.Y., Aug. 22, 1977).

113. Id., slip op., at 4 . 
school district on the ground that it was in violation of the state tenure law. ${ }^{14}$ When the state courts ruled that under New York law there could be no special tenure for bilingual or ESL teachers, school officials were forced to lay off junior teachers, who included most of the teachers in the bilingual and ESL programs. ${ }^{115}$ This in turn prompted the Cintron plaintiffs, parents of Puerto Rican and other Hispanic children who had English-language deficiencies, to file suit in federal court to challenge the school district's action. Neither they nor the bilingual and ESL teachers who were laid off had been parties to the state-court proceedings. The Cintron plaintiffs argued that the state tenure law requiring layoffs in order of seniority conflicted with their federally guaranteed right to bilingual education, ${ }^{116}$ in violation of the supremacy clause of the Constitution. ${ }^{117}$ The court denied the school district's motion to dismiss, observing that "where compliance with both federal and state regulations is an impossibility, the state enactments must give way." 118

The Attorney General of the State of California has issued an opinion which construes that state's tenure law so as to avoid the conflict which led to the Cintron litigation. California tenure law requires the retention of senior teachers over junior teachers when they are "competent to render" the service needed. ${ }^{19}$ The construction placed on this statute, however, is as follows: the "ability to teach in a bilingual education program is a competency which will permit a school district [that has adopted such a program] to retain junior employees." 120 Thus conflict between state and federal law is avoided. Where state law does not permit such flexibility, however, the conflict may be inevitable, and under the rationale of the Cintron decision would likely be resolved in favor of retaining bilingual teachers in order to fulfill the federal requirements. ${ }^{121}$

114. Morris v. Brentwood Union Free School Dist., 49 App. Div. 2d (1975), aff'd, 52 App. Div. 2d 584, leave to appeal denied; 40 N.Y.2d 802 (1976).

115. Further highlighting the classical nature of the confrontation, the plaintiffs in the Morris case returned to state court after their victory and sought to enjoin the Brentwood school district from placing them in teaching situations requiring them to speak Spanish. On December 31, 1976, a motion for preliminary injunction was granted. Brentwood Teachers' Assn. v. Brentwood Union Free School Dist., No. 76-14146 (N.Y. Sup. Ct. Oct. 5, 1976).

116. See 20 U.S.C. $\$ \$ 880($ b), $1703($ f) $(1976) ; 42$ U.S.C. $\$ 2000$ (d) (1976); 42 C.F.R. $\$ \S 80,123$ (1978). The Cintron court construed these enactments as articulating a strong federal policy in favor of bilingual education. See discussion at notes 87 and 109 supra, and accompanying text.

117. U.S. Const, art. 6, cl. 2.

118. Cintron v. Brentwood Union Free School Dist. Bd. of Educ, No. 77-C-1310, slip op. at 17 (E.D.N.Y. Aug. 22, 1977). The court left for resolution at trial whether and to what extent staff cutbacks by the school district were mandated by state law or required by a possible common-law fiduciary duty of the local school officials. Until this issue was resolved, the court could not determine the "complex factual question" of the impossibility of the school district's complying with both the state tenure law and the federal enactments. Id. at 19 .

119. Cal. [Educ.] Code $\$ 44955$ (West 1978).

120. 60 Op. Cal. Att'y Gen. 80, 81 (1977). See also 59 Op. Cal. Att'y Gen. 73 (1976).

121. An even more difficult problem politically is whether a school district must recruit and 
There still remains the genuine problem of the limited number of trained bilingual teachers currently available to teach those students who have already been diagnosed as in need of bilingual instruction. Part of the problem, some have suggested, may be blamed on existing certification requirements. It is beyond the scope of this paper to discuss all of the possible ways in which certification requirements may unreasonably restrict the number of bilingual teaching applicants. However, one obvious barrier to certification which some states have raised is the citizenship requirement. ${ }^{122}$ This clearly limits the pool of bilingual teachers. Such a requirement seems to violate the principles enunciated in In re Griffiths ${ }^{123}$ and Sugarman $v$. Dougall, ${ }^{124}$ and one court has so held. ${ }^{125}$ Another possible barrier that may unreasonably restrict the hiring of bilingual teachers is the use of the National Teachers Examination or the Graduate Record Examination for certification or employment. The Supreme Court recently summarily affirmed a decision which required that the $\mathrm{Na}$ tional Teachers Examination, in accordance with the mandate of Title VII of the Civil Rights Act of $1964,{ }^{126}$ be professionally validated as predictive of or significantly correlated with performance in the job for which the applicant is being evaluated. ${ }^{127}$ Thus these or similar tests which are being used for certification or employment may be challenged on the ground that they do not adequately predict or measure the ability to perform as a bilingual teacher.

\section{VI}

\section{Desegregation and Bilingual Education-A Conflict?}

Most of the case law of school desegregation has responded to the unconstitutional discrimination against blacks in the Deep South and border states. Thus both the constitutional violation and the appropriate remedy have been viewed exclusively in the context of black-white relations. As the movement to

hire bilingual teachers to replace non-bilingual teachers currently employed by the system. With declining non-Hispanic enrollments and increasing or constant Hispanic enrollments, it is clear that without hiring additional bilingual teachers, some LESA children will not be receiving bilingual instruction from teachers who have the requisite language skills. Although many school districts have attempted to cope with this problem by using bilingual aides in classrooms with monolingual English-speaking teachers, this appears to violate the spirit, if not the letter, of the federal mandate.

122. See, e.g., TEx. [EDuc.] Code Ans. tit. 2, § 13.044 (Vernon 1972).

123. 413 U.S. 717 (1973) (Citizenship requirement to take the state bar examination violates equal protection clause of the fourteenth amendment).

124. 413 U.S. 634 (1973) (Citizenship requirement to hold permanent position in the competitive class of state civil service violates equal protection clause of the fourteenth amendment).

125. Norwick v. Nyquist, 417 F. Supp. 913 (S.D.N.Y. 1976). The Supreme Court has agreed to hear arguments in appeal from the decision, 436 U.S. 902 (1978).

126. 42 U.S.C. $\$ 2000 \mathrm{e}-12$ (1976); 29 C.F.R. $\$ 1607$ (1978).

127. United States v. South Carolina, 445 F. Supp. 1094 (D.S.C. 1977), aff'd mem., 434 U.S. 1026 (1978); United States v. North Carolina, 400 F. Supp. 343 (E.D.N.C.), vacated, 425 F. Supp. 789 (E.D.N.C. 1977). 
desegregate schools has shifted from the South to Northern and Western cities, an additional element has entered the picture. At times the goal of equal educational opportunity for black children, which is reached through pupil reassignment to end racial and ethnic isolation, has appeared to be in direct conflict with the goal of equal educational opportunity for Hispanic children, which requires the separation of ethnic groups for bilingual-bicultural instruction.

While there certainly is tension between the two concepts, conflict is not inevitable. There will be instances, however, in which black and Hispanic communities lock horns over this issue. Where after a prolonged struggle Hispanic communities have managed to obtain bilingual education programs for their children, they will view with suspicion any changes imposed from the outside which seem to impinge upon these programs. Whether correctly or incorrectly, many advocates of bilingual education fear that dispersal of Hispanic students and of the bilingual programs now situated in the barrio will dissipate whatever influence they have over those programs. They fear that through integration the assimilationist sentiment of an Anglo majority may jeopardize bilingual programs. One likely consequence of this concern will be an effort to retain the segregated status quo. Whatever the validity of these arguments, it must be remembered that the debate over desegregation has always been heavily influenced by emotion, perceived political gain or loss, and unsupported suppositions about educational advantages or disadvantages. Hispanic plaintiffs have sought to intervene at the remedial phase of desegregation litigation initiated by blacks in order to insure that their special concerns are considered in any desegregation decree, and courts are now beginning to recognize that the linguistic needs of Hispanic students must be given consideration in desegregation orders.

The threat to bilingual instruction is that a desegregation decree seeks to break up racially or ethnically isolated schools and disperse their students throughout the system. If all children in need of bilingual education programs were dispersed without consideration of that need, it is unlikely in most communities that there would be sufficient numbers of children in any school or area to justify separate classes for comprehensive bilingual-bicultural instruction. It is thus necessary to insure that sufficient numbers of LESA students are grouped together.

In Keyes v. School District No. $1,{ }^{128}$ in response to a proposal put forward by the Hispanic intervenors, the Denver school district was ordered to develop a pilot bilingual-bicultural program which was to be implemented in several schools. The district court, acknowledging the desire of Hispanic students not

128. 380 F. Supp. 673 (D. Colo. 1974). 
to be dispersed if dispersal meant sacrificing bilingual instruction, ${ }^{129}$ held that desegregation was not in the best interests of the community ${ }^{130}$ and declined to include some of these pilot schools in the pupil reassignment plan.

However, on appeal the Tenth Circuit reversed this part of the district court's order, observing:

Bilingual education . . . is not a substitute for desegregation. Although bilingual instruction may be required to prevent the isolation of minority students in a predominantly Anglo school system ... such instruction must be subordinate to a plan of school desegregation. ${ }^{131}$

The Boston desegregation decree has served as a model for dealing with Hispanic students in the context of what is otherwise a black-white case. ${ }^{132}$ The decree ordered the assignment of LESA students before others, to prevent their dispersal. ${ }^{133}$ The court resolved the problem by initially concluding that three consecutive bilingual classes were the minimum necessary for an effective program of bilingual instruction, which would mean an enrollment of sixty LESA students-twenty students for each grade level. Then the court determined how large the minority population in each school should be. ${ }^{134}$

129. Id. at 687,692 .

130. Id. at 692 .

131. 521 F.2d 465, 480 (10th Cir. 1974), cert. denied, 423 U.S. 1066 (1976).

132. It should be noted, however, that Massachusetts has a law mandating bilingual education. Mass. Ann. Laws ch. $71 \mathrm{~A}, \S 2$ (Michie/Law. Co-op 1978). Thus, one might expect that a court, in ruling on a desegregation plan, would be more likely to ensure that state or federally created rights to bilingual education are not infringed by the plan, see Cintron v. Brentwood Union Free School Dist. Board of Educ., 455 F. Supp. 57 (E.D.N.Y. 1978), than to require such education as part of a desegregation plan where no pre-existing right to such education had been established. See, e.g., Keyes v. School Dist. No. 1, 521 F.2d 465 (10th Cir, 1975), cert. denied, 423 U.S. 1066 (1976). But cf. Milliken v. Bradley, 433 U.S. 267 (1977) (a federal court may order compensatory and remedial educational programs to eliminate the effects of prior unlawful pupil assignments).

133. Morgan v. Kerrigan, 401 F. Supp. 216, 242, 252 (D. Mass. 1975), aff'd, 530 F.2d 401 (1st Cir.), cert. denied, 426 U.S. 935 (1976).

134. One issue that, it is hoped, has finally been resolved is whether in the context of white desegregation, Hispanos, for whom no finding of de jure segregation has been made, are to be considered a minority. A common practice in Texas was for school districts to classify Hispanic students as white; the school districts would then integrate by mixing black and Hispanic students. This practice has since been held invalid. As the Fifth Circuit observed in Ross v. Eckels, 468 F.2d 649, 650 (5th Cir. 1972):

No remedy for the dual system can be acceptable if it operates to deprive members of a third ethnic group of the benefits of equal educational opportunity. . . To exclude Mexican-Americans from the benefits of tri-partite integration in the very act of effecting a unitary system would be to provide blacks with the benefit of integration while denying it to another ... group on the basis of ethnic origin.

See also Keyes v. School Dist. No. 1, 413 U.S. 189, 198 (1973); United States v. Texas Educ. Agency, 467 F.2d 848, 870 (5th Cir. 1972) (en banc); Evans v. Buchanan, 416 F. Supp. 328, 359 (D. Del. 1976), modified and aff'd, 555 F.2d 373 (3d Cir.), cert. denied, 434 U.S. 880 (1977); Cisneros v. Corpus Christi Indep. School Dist., 324 F. Supp. 599, 604-06 (S.D. Tex. 1970), aff'd in part, modified in part, and remanded, 467 F.2d 142 (5th Cir.), cert. denied, 413 U.S. 920 (1972). This aspect of Cisneros and Keyes is discussed in Levin \& Moise, supra note 73, at 50, 77. 
For example, a previously all-white school might be required to have a student population that was $\mathbf{4 0}$ percent minority under the desegregation decree. If the sixty LESA students necessary for an effective bilingual program brought the minority percentage of that school to 20 percent, then the remaining 20 percent of the minority students would be black. Thus, LESA students first had to be identified, the minimally acceptable number of such students for effective bilingual instruction had to be determined, and finally, only after LESA students were assigned would the other minority students and the Anglo students be assigned. This same approach has been followed in Wilmington, Delaware ${ }^{135}$ and Buffalo, New York. ${ }^{136}$

The Tenth Circuit's ruling in Keyes that the retention of entirely segregated schools cannot be justified in the name of bilingual education need not pose a threat to ethnically identifiable bilingual classes situated in otherwise integrated settings. Indeed, the Supreme Court implied that in certain limited circumstances separate classes for bilingual education may be appropriate when in Lau $v$. Nichols ${ }^{137}$ it expressly referred to the following HEW regulations:

Any ability grouping or tracking system employed by the school system to deal with special language skill needs of national origin-minority group children must be designed to meet such language skill needs as soon as possible and must not operate as an educational dead end or permanent track. ${ }^{138}$

Regulations promulgated under the Emergency School Aid Act (ESAA) ${ }^{139}$ provide the clearest indication of HEW's view of ethnically identifiable classes, although the Act itself is applicable only to ESAA grantees. ${ }^{140}$ ESAA regulations clearly permit classes to be ethnically separated for less than 25 percent of the school day. ${ }^{141}$ Classes isolated ethnically for longer may be justified only if they can be shown to be in accord with standard pedagogical practices. ${ }^{142}$ Bona fide ability grouping is defined as follows:

135. Evans v. Buchanan, 416 F. Supp. 328, 359 (D. Del. 1976).

136. Arthur v. Nyquist, 415 F. Supp. 904 (W.D.N.Y. 1976), aff'd in part, 573 F.2d 134 (2d Cir.), cert. denied, 99 S. Ct. 179 (1978).

137. 414 U.S. 563, 568 (1974).

138. 35 Fed. Reg. 11595 (1970).

139. 20 U.S.C. $\$ \$ 1601-1619$ (1976).

140. ESAA funds are available to school districts which are undergoing desegregation to help reduce the isolation of minority students and to help such students overcome the educational handicaps caused by past isolation.

141. 45 C.F.R. $\$ 185.43$ (c) (1978). Board of Educ. of the City School Dist. of Cincinnati v. HEW, 396 F. Supp. 203 (S.D. Ohio 1975), rev'd on other grounds, 532 F.2d 1070 (6th Cir. 1976) addresses these regulations, and their meaning is still far from clear. Plaintiffs contended that $\S$ 185.43(c), which prohibits isolation for more than 25 percent of the day is an unreasonable interpretation of the statute, 20 U.S.C. $\$ 1605(d)(1)(C)(1976)$, which prohibits isolation "for a substantial portion of the school day." The court held that the rule was practical and realistic. Id. at 239. See also McNeal v. Tate County School Dist., 508 F.2d 1017, 1021 (5th Cir. 1975).

142. 45 C.F.R. $\S 185.43$ (c) (1978). 
[It] is based upon non-discriminatory, objective standards of measurement which are educationally relevant to the purposes of such grouping and which, in the case of national origin minority group children, do not essentially measure English language skills; ... [which are] maintained for only such portion of the school day ... as is necessary to achieve the purposes of such grouping; ... [ [which are] designed to meet the special needs of the students ... and to improve the academic performance and achievement of students determined to be in the less academically advanced groups, by means of specially developed curricula, specially trained or certified instructional personnel, and periodic retesting to determine academic progress and eligibility for promotion; and ... [ [which are] validated by test scores or other reliable objective evidence indicating the educational benefits of such grouping. ${ }^{143}$

It is clear that the prohibition against ethnically identifiable ability grouping "which, in the case of national origin minority group children, . . . essentially measure[s] English language skills," ${ }^{144}$ is not directed toward programs of bilingual instruction. The harm which the regulation as a whole sought to prevent was the disproportionate assignment of language minority students to classes for the educable mentally retarded or to non-academic tracks based on English language tests. ${ }^{145}$ Thus, although the remaining provisions of this regulation are clearly applicable requirements for programs of bilingual instruction, this particular provision should not be interpreted to interfere with the assignment of LESA students to ethnically identifiable bilingual classes resulting from an assessment of their English language skills. Indeed, the other provisions-that ethnically separate classes for bilingual instruction be only for that portion of the day necessary for an effective program, ${ }^{146}$ and that the separation be justified educationally--are undoubtedly appropriate given the dangers inherent in any assignment of students to classes or groups on the basis of ethnic identity.

Where bilingual programs of instruction are provided for LESA students, are school districts obligated to include non-language-minority students in the program? Some legislation, at both the federal and state levels, has either

143. 45 C.F.R. $\$ 185.43(c)(1)(4)(1978)$.

144. 45 C.F.R. $\$ 185.43$ (c)(1) (1978).

145. See, e.g., Diana v. State Bd. of Educ., Civ. No. C-70-37-RFR (N.D. Cal. June 18, 1973); Covarrubius v. San Diego Unified School Dist., Civ. No. 70-394-5 (S.D. Cal. Aug. 21, 1972); Guadalupe Organization, Inc. v. Tempe Elementary School Dist., Civ. No. 71-435 (D. Ariz. May 9, 1972). See Levin and Moise, supra note 73, at 126-27 \& nn. 474-77; U.S. Comm'n on CiviL Rights: Mexican American Education Study, Report 6: Toward Quality Education for Mexican Americans 59 (1974). See also Center for Law and Education, Classification MateRIALS 199-207, 224-29, 429 (rev. ed. 1973).

146. Most bilingual education legislation requires that LESA students be integrated with other non-LESA students for subjects in which language skills are less important. See, e.g., Bilingual Education Act, 20 U.S.C.A. \$ 3223(a)(4)(c) (West Supp. 1979); MAss. Ans. LAws ch. 71 A, 85 (Michie/Law. Co-op. 1978); but see Roos \& Roos, The Massachusetts Transitional Bilingual Education Act: Problems in the Classroom and Possible Legislative Responses, 19 Inequality in Educ. 38, 40 (Feb. 1975). 
encouraged $^{147}$ or in some cases required the inclusion of such children. ${ }^{148}$ The explanation for inclusion of non-language-minority children was given by then Special Assistant to the Director, and later, Director, of the Office of Civil Rights, who observed that "to meet the needs of ethnically isolated children ... participation of Anglo children in the bicultural/bilingual programs is essential."149 Thus although the primary focus of bilingual education must be the LESA student, there is still an obligation to see that his education occurs in the most integrated setting possible. ${ }^{150}$ Almost no research, however, has been undertaken on the impact of non-language minorities-and their relative proportions in the class-on bilingual instruction for LESA students.

A New York federal district court has recently held that a bilingualbicultural program which segregated Spanish-speaking students from the rest of the student body except for physical education and lunch was in violation of federal law. ${ }^{151}$ The court pointed out that keeping such students separate from English-speaking students for instruction in art and music was a clear violation of the Lau Guidelines. ${ }^{152}$ Moreover, the retention of students in the bilingual program who had attained sufficient proficiency in English to enable them to comprehend regular English instruction "was a perversion of the purpose [of the Title VII program] and a misuse of funds." 153 The court then quoted the following language of the Equal Educational Opportunities Act:

No state shall deny equal educational opportunity to an individual on account of his or her ... national origin, by-

(a) the deliberate segregation by an educational agency of students on the basis of . . national origin, among or within schools. ${ }^{154}$

It should be noted that the court did not necessarily condemn maintenance bilingual-bicultural programs per se, but emphatically rejected maintenance

147. See, e.g., 20 U.S.C. \& 3223(a)(4)(B) (West Supp. 1979); N.J. Stat. AnN. \& 18A: 35-20 (West Cum. Supp. 1979); Colo. Rev. Stat. $\$ 22-24-112(6)$ (Cum. Supp. 1978).

148. See, e.g., R.I. GEN. LAws § 16-54-5(b) (Cum. Supp. 1979); Ind. Code Ann. § 20-10.1-5.5-3 (Burns Cum. Supp. 1977).

149. M. Gerry, Cultural Freedom in the Schools: The Right of Mexican American Children to Succeed (unpublished paper, Office for Civil Rights, U.S. Dep't of Health, Education, and Welfare) (1971).

150. The regulations implementing the Bilingual Education Act, however, require that priority for placement in bilingual programs be given to LESA students, and that the number of nonlanguage minority students be limited. 45 C.F.R. $\S 123.02(\mathrm{~g})(2)(\mathrm{i})(1978)$.

Two courts, in pre-Lau decisions, in ordering bilingual-bicultural instruction for Chicanos, also required Anglo students to be included. Serna v. Portales Municipal Schools, 499 F.2d 1147, 1151 (10th Cir. 1974); United States v. Texas, 342 F. Supp. 24, 28 (E.D. Tex. 1971), aff'd per curiam, 466 F.2d 518 (5th Cir. 1972). See also Cardenas, Bilingual Education, Segregation and $A$ Third Alternative, 19 Inequality in Educ. 19 (Feb. 1975).

151. Cintron v. Brentwood Union Free School Dist. Bd. of Educ, 455 F. Supp. 57, 60, 63 (E.D.N.Y. 1978)

152. Id. at $63 \& \mathrm{n} .9$.

153. Id.

154. 20 U.S.C. $§ 1703(\mathrm{a})$ (1976). 
programs which operated to isolate students in ethnically identifiable classes. However, the court concluded its opinion by ordering increased contact between non-English and English speaking children and establishment of a method for transferring students out of the program when the necessary level of English proficiency was attained. ${ }^{155}$

\section{Conclusion}

Increasingly, judicial, legislative, and administrative mandates are requiring school districts to provide comprehensive programs of bilingual-bicultural instruction taught by competent bilingual personnel. This recognition that linguistically different children have a right to a linguistically different education is clearly overdue. While no definitive conclusions can be drawn from the existing social science research about the relative merits of the different approaches for meeting the needs of students of limited English speaking ability, it is clear that government policy is moving in the direction of bilingualbicultural education, in the belief that by offering an effective and responsive education, ethnic barriers and segregation will eventually be eliminated.

155. Cintron v. Brentwood Union Free School District Bd. of Educ., 455 F. Supp. 57, 64 (E.D.N.Y. 1978). 